\title{
WHO recommends eight week abstinence or safer sex after return from Zika areas
}

\author{
Michael McCarthy
}

Seattle

To prevent sexual transmission of the Zika virus, people who return from areas of active Zika transmission who have no symptoms of infection should still abstain from sex or use safer sex practices for at least eight weeks, the World Health Organization has said. ${ }^{1}$

"This goes for men and women," said Christian Lindmeier, WHO spokesman, at a press briefing in Geneva, Switzerland. WHO's previous recommendation was safer sex or just four weeks of abstinence, given to travellers returning from endemic areas without symptoms.

If a couple is planning a pregnancy and the male partner has developed symptoms of Zika virus infection-which include rash, fever, arthralgia, myalgia, and conjunctivitis - the couple should extend the period of safer sex or abstinence to six months, Lindmeier said. "This is the time [needed] to ensure that the infection has left the body and [that] the virus will not be passed on to the fetus or partner," he said.

Couples planning a pregnancy who live in areas with known local transmission of Zika virus should consider delaying the pregnancy, he added. WHO has recommended that pregnant women's sexual partners who live in or are returning from known areas of local Zika transmission should practise safer sex or abstain for at least the duration of the pregnancy.

The US Centers for Disease Control and Prevention has said that Zika virus can be passed from a man to a female or male sexual partner by vaginal, oral, or anal sex either before symptoms begin, while symptomatic, or after symptoms have resolved. After infection, Zika virus can persist in semen longer than in the blood. It is not yet known, however, whether a man who has had asymptomatic infections can transmit the virus sexually or whether an infected woman can transmit the virus to her sexual partner.

1 World Health Organization. Zika virus and complications: questions and answers. Updated 31 May 2016. www.who.int/features/qa/zika/en/.

Published by the BMJ Publishing Group Limited. For permission to use (where not already granted under a licence) please go to http://group.bmj.com/group/rights-licensing/ permissions 
Figure

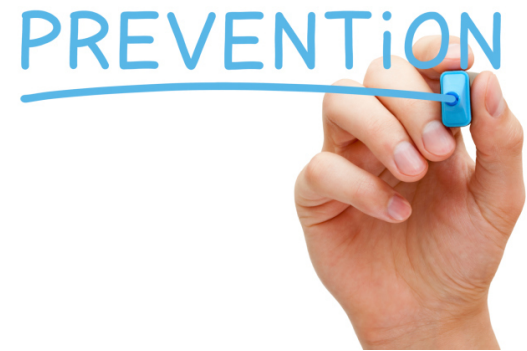

